\title{
Thermal [2+2]-cycloadditions of diphenylketene with aryl- and
} hetaryl-substituted thioketones

Mlostoń, Grzegorz ; Urbaniak, Katarzyna ; Szychowska, Anna ; Linden, Anthony ; Heimgartner, Heinz

Abstract: The reaction of diphenylketene (1) with aryl- and hetaryl-substituted thioketones (2) gave the corresponding 3,3,4,4-tetraarylthietan-2-ones (3) in good yields. Remarkably, the reactions with bishetaryl-substituted thioketones occurred significantly faster compared with those involving the bis-arylsubstituted thioketones. The structure of compound 3c has been established by X-ray crystallography.

DOI: https://doi.org/10.3987/COM-14-S(K)56

Posted at the Zurich Open Repository and Archive, University of Zurich ZORA URL: https://doi.org/10.5167/uzh-97976

Journal Article

Accepted Version

Originally published at:

Mlostoń, Grzegorz; Urbaniak, Katarzyna; Szychowska, Anna; Linden, Anthony; Heimgartner, Heinz (2015). Thermal [2+2]-cycloadditions of diphenylketene with aryl- and hetaryl-substituted thioketones. Heterocycles, 90(1):529-539.

DOI: https://doi.org/10.3987/COM-14-S(K)56 
HETEROCYCLES, Vol. 90, No. 1, 2014, pp. -. ( 2014 The Japan Institute of Heterocyclic Chemistry

Received, 29th June, 2014, Accepted, 29th July, 2014, Published online, 6th August, 2014

DOI: $10.3987 / C O M-14-S(K) 56$

\title{
THERMAL [2+2]-CYCLOADDITIONS OF DIPHENYLKETENE WITH ARYL- AND HETARYL-SUBSTITUTED THIOKETONES
}

\section{Grzegorz Mlostoń, ${ }^{a *}$ Katarzyna Urbaniak, Anna Szychowska, ${ }^{1, a}$ Anthony Linden, and Heinz Heimgartner ${ }^{\mathrm{b} *}$}

a: University of Łódź, Department of Organic and Applied Chemistry, Tamka 12, PL-91-403 Łódź, Poland: e-mail: gmloston@uni.lodz.pl

b: University of Zurich, Department of Chemistry, Winterthurerstrasse 190, CH-8057 Zurich, Switzerland; e-mail: heinz.heimgartner@chem.uzh.ch

Dedicated to Professor Dr. Isao Kuwajima on the occasion of his $77^{\text {th }}$ birthday

\begin{abstract}
The reaction of diphenylketene (1) with aryl- and hetaryl-substituted thioketones (2) gave the corresponding 3,3,4,4-tetraarylthietan-2-ones (3) in good yields. Remarkably, the reactions with bis-hetaryl-substituted thioketones occurred significantly faster compared with those involving the bis-aryl-substituted thioketones. The structure of compound $\mathbf{3 c}$ has been established by X-ray crystallography.
\end{abstract}

\section{INTRODUCTION}

Among heterocumulenes, ketenes are widely applied in cycloaddition reactions as highly reactive dienophiles and dipolarophiles. ${ }^{2}$ In addition, they easily undergo [2+2] cycloadditions with diverse $\mathrm{C}=\mathrm{X}$ groups, yielding four-membered heterocycles $(X=N, O)^{3}$ or cyclobutane derivatives $(X=C) .{ }^{3 a, 4}$ Whereas reactions of ketenes with imines are extensively studied as one of the most important methods for the synthesis of $\beta$-lactams, similar [2+2] cycloadditions with thioketones are rarely reported and some contradictions exist. ${ }^{5}$ The study performed with diphenylketene (1) and thiobenzophenone (2a) as well as its para-substituted derivatives shows that thietan-2-ones of type $\mathbf{3 a}$ are the products of the reaction with aromatic thioketones (Scheme 1). ${ }^{5 \mathrm{c}}$ The analogous structure was attributed to the product obtained in the reaction with methyl dithiobenzoate. ${ }^{6}$ A thietan-2-one was also formed via photocycloaddition of 9H-xanthene-9-thione with $\mathbf{1}^{7}$ However, the reaction of $\mathbf{1}$ with the in situ generated aryl cinnamoyl thioketone follows the hetero-Diels-Alder pathway leading to 3,4-dihydro- $H$-thiopyran-2-one derivatives. $^{8}$ 
Reactions of diphenylketene (1) with aliphatic and cycloaliphatic thioketones are almost unknown. The reaction with the enolizable diisopropyl thioketone (4a) is reported to yield the vinyl thioester (5) as the exclusive product. $^{9}$ The formation of products of type $\mathbf{3}$ is believed to occur via a concerted [2+2] cycloaddition reaction. However, in a recent publication, the reaction of adamantanethione (4b) with $\mathbf{1}$ is reported to give the 2:1-cycloadduct (6). ${ }^{10}$ On the other hand, the product formed in the reaction of $\mathbf{1}$ with pivaloyl thioaldehyde (7) was identified as the 1:2-cycloadduct $(\mathbf{8}) .^{11}$

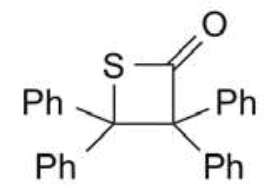

$3 a$

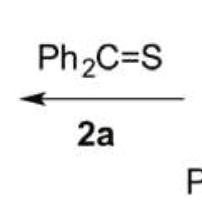

1<smiles>CCC(SC(=O)C=[SH]c1ccccc1)=C(C)C</smiles>

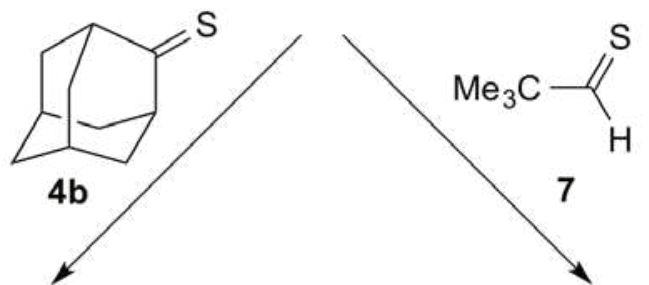<smiles>Pc1ccccc1</smiles>

6<smiles>CC1SC(=O)C(c2ccccc2)(c2ccccc2)C(C)S1</smiles>

8

Scheme 1

In general, thioketones are prone dienophiles and dipolarophiles, which react with some 1,3-dipoles, e.g., with gem-diaryl thiocarbonyl $S$-methanides (thiocarbonyl ylides), in a non-concerted manner via diradical intermediates. ${ }^{12}$ Due to our ongoing interest in applications of thiocarbonyl compounds for the synthesis of sulfur-containing heterocycles, and, on the other hand, in the mechanism of cycloadditions and the reactivity of $\mathrm{C}=\mathrm{S}$ compounds, we studied the reactions of $\mathbf{1}$ with a series of aryl- and hetaryl-substituted thioketones.

\section{RESULTS AND DISCUSSION}

Whereas aryl-substituted thioketones such as thiobenzophenone (2a), thiofluorenone (2b), dibenzosuberenethione (2c), and dibenzosuberanethione (2d) are well known and frequently applied as model thioketones, their hetaryl analogues $\mathbf{2 e}-\mathbf{2} \mathbf{i}$ are scarcely described. In a recent publication, we reported a method for the synthesis of a series of symmetrical and non-symmetrical representatives, 
which were subsequently used for selected 1,3-dipolar cycloadditions and hetero-Diels-Alder reactions. ${ }^{13}$ The goal of the present study was to examine reactions of both aryl- and hetaryl-thioketones with diphenylketene (1).

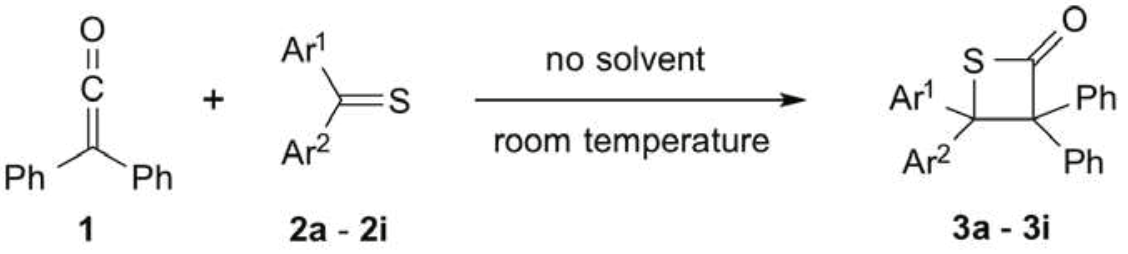

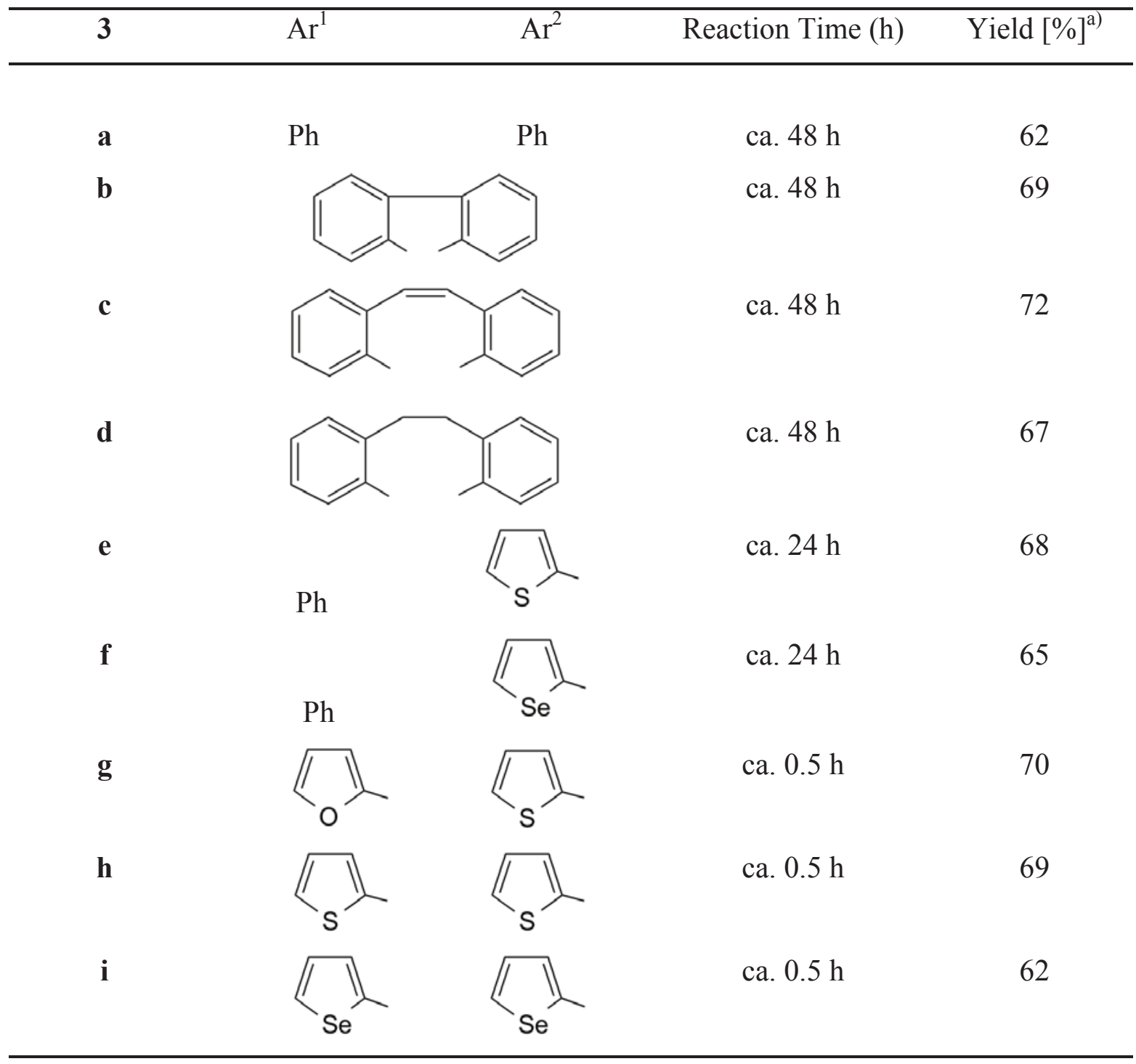

a) Yields of isolated products.

Scheme 2

As a test experiment, freshly prepared $\mathbf{1}$ was reacted with $\mathbf{2 a}$ without any solvent at room temperature. After two days, the blue color of $\mathbf{2 a}$ vanished, and the major product was isolated after chromatography 
$\left(\mathrm{SiO}_{2}\right)$ and its structure 3a was established based on the spectroscopic data. ${ }^{5}$ In the ${ }^{13} \mathrm{C}-\mathrm{NMR}$ spectrum, two signals of quaternary $\mathrm{C}$-atoms absorbed at 63.5 and $93.2 \mathrm{ppm}$, proving the structure reported in the literature. The minor product isolated as colorless crystals was identified as benzophenone $\left({ }^{13} \mathrm{C}-\mathrm{NMR}\right.$ : $196.6 \mathrm{ppm}(\mathrm{C}=\mathrm{O}))$.

Similarly, reactions of $\mathbf{1}$ with $\mathbf{2 b}-\mathbf{2 d}$ occurred smoothly at room temperature yielding the corresponding thietan-2-one derivatives $\mathbf{3 b}-\mathbf{3 d}$ as crystalline materials (Scheme 2). In all these cases, the reaction times were comparable with the thiobenzophenone experiment (ca. $48 \mathrm{~h}$ ), and the ${ }^{13} \mathrm{C}-\mathrm{NMR}$ analysis of the crude reaction mixtures revealed the presence of benzophenone. The structure of $\mathbf{3 c}$ was unambiguously established by X-ray crystallography (Figure).

The reactions of $\mathbf{1}$ with hetaryl-substituted thioketones $(\mathbf{2} \mathbf{e}-\mathbf{2 i})$ were performed in an analogous manner. Whereas the reactions with the non-symmetrical thioketones (2e, $2 \mathbf{f})$ were completed after ca. $24 \mathrm{~h}$, the bis-hetaryl analogues $(\mathbf{2 g}-\mathbf{2} \mathbf{i})$ reacted vigorously, and the color of the thioketone had already disappeared after $0.5 \mathrm{~h}$. Again, traces of benzophenone were identified in the crude mixtures obtained in the reactions with $\mathbf{2 e}$ and $\mathbf{2 f}$, but it could not be detected in reactions involving the most reactive hetaryl-thioketones $(\mathbf{2 g}-\mathbf{2 i})$. The corresponding thietan-2-ones $(\mathbf{3 e}-\mathbf{3 i})$ were isolated by chromatographic workup and were obtained as crystalline materials, which, upon heating to the melting point temperature, colorized due to decomposition via release of the respective thioketone. In the case of the Se-containing products (3f) and (3i), slow decomposition during storage at room temperature was observed.

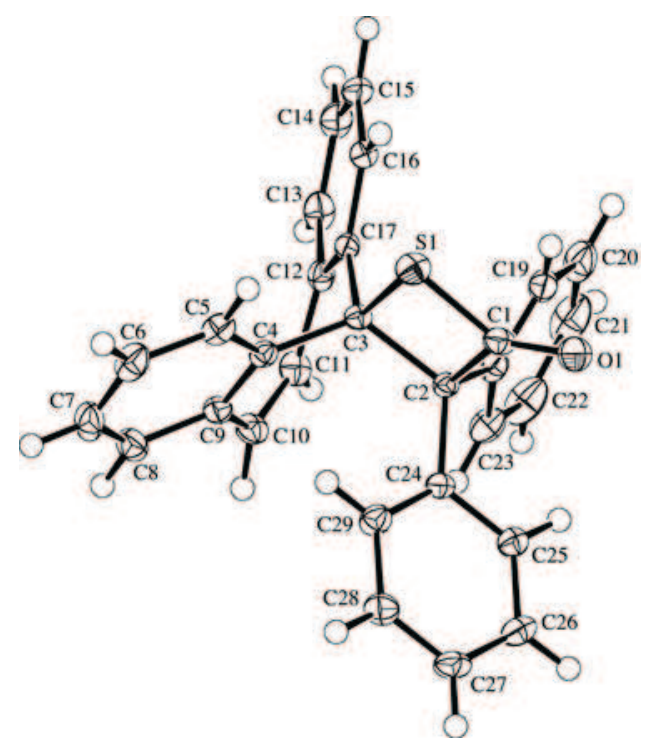

Figure. ORTEP plot $^{14}$ of the molecular structure of 3c (arbitrary numbering of the atoms; 50\% probability ellipsoids) 
It is well established that sulfur heterocycles such as 1,2,4-trithiolanes can be selectively oxidized to give the corresponding S-oxides. ${ }^{15}$ In the case of 3,3,4,4-tetraphenylthietan-2-one (3a), the attempted oxidation with excess mCPBA in $\mathrm{CH}_{2} \mathrm{Cl}_{2}$ at $50{ }^{\circ} \mathrm{C}$ over $18 \mathrm{~h}$ was reported to yield a mixture of products, but the expected S-oxide was not obtained. ${ }^{16}$ In our experiments, $\mathbf{3 a}$ and $\mathbf{3 e}$ were treated with ca. equimolar amounts of mCPBA in $\mathrm{CH}_{2} \mathrm{Cl}_{2}$ solution at room temperature for $24 \mathrm{~h}$. In both cases, no oxidation occurred and the starting materials were recovered. In order to get the desired S-oxides of compounds $\mathbf{3}$, we also tested the reaction of $\mathbf{1}$ with thiobenzophenone S-oxide ${ }^{17}$ using the same procedure as in the reactions of $\mathbf{1}$ with $\mathbf{2 a}$. The only product identified after separation of the mixture was benzophenone.

Whereas reactions of $\mathbf{1}$ with ethylene derivatives or with imines are believed to occur in a concerted manner, the corresponding reactions with thioketones were suggested to proceed via a zwitterionic intermediate. ${ }^{8}$ In the case of adamantanthione and pivaloyl thioaldehyde, the experimental proof for the stepwise reaction mechanism is the formation of $1: 2^{10}$ or $2: 1^{11}$ adducts, respectively. The mechanism of the reaction of $\mathbf{1}$ with some $\alpha, \beta$-unsaturated aryl thioketones was also suggested to occur via a stepwise mechanism. ${ }^{8}$ In the present study, the reactions with aryl- and hetaryl-thioketones (2) seem to follow a concerted pathway, as no product resulting from the intermediacy of a zwitterionic or a diradical species was observed. Apparently, the formation of benzophenone found in the mixtures after slow reactions of $\mathbf{1}$ with aromatic thioketones $(\mathbf{2 a}-\mathbf{2 f})$ resulted from a side reaction of diphenylketene itself. ${ }^{20}$

\section{CONCLUSIONS}

The present study shows that aryl- and hetaryl-thioketones of type 2 react with diphenylketene (1) analogously to the reaction with thiobenzophenone (2a), to give the expected thietan-2-ones (3). However, bis-hetaryl thioketones $(\mathbf{2} \mathbf{g}-\mathbf{2} \mathbf{i})$ are significantly more reactive, and their reactions with $\mathbf{1}$ occur without the formation of benzophenone as a side product. Most likely, the reaction mechanism follows a concerted [2+2] cycloaddition pathway. It is worth mentioning that the hetaryl-thioketones react with $\mathbf{1}$ to give exclusively [2+2] cycloadducts. The products of the alternative hetero-Diels-Alder reactions with $\mathbf{1}$ acting as dienophile ${ }^{21 \mathrm{a}-21 \mathrm{c}}$ and hetaryl-thioketones as heterodienes ${ }^{13}$ were not observed. Finally, the smooth reaction of the non-symmetrical hetaryl-thioketones $(\mathbf{2 g}-\mathbf{2 i})$ with $\mathbf{1}$ opens a new way for studying hitherto unknown asymmetric [2+2] cycloadditions ${ }^{21 \mathrm{~d}}$ leading to thietan-2-ones.

\section{EXPERIMENTAL}

General remarks. Melting points were determined in a capillary using a Melt-Temp. II (Aldrich) apparatus, and they are uncorrected. The IR spectra were recorded on a NEXUS FT-IR spectrophotometer in $\mathrm{KBr}$; absorptions in $\mathrm{cm}^{-1}$. The ${ }^{1} \mathrm{H}$ - and ${ }^{13} \mathrm{C}\left\{{ }^{1} \mathrm{H}\right\}$-NMR spectra were measured on a Bruker Avance III instrument (600 and $150 \mathrm{MHz}$, resp.) using solvent signals as reference. Chemical shifts $(\delta)$ are given in 
ppm and coupling constants $J$ in Hz. HR-ESI-MS were recorded on a Bruker maXis spectrometer in the Laboratory of Mass Spectrometry of the University of Zurich, and the TOF-MS for $\mathbf{3 h}$ was registered on a SYNAPT G2-Si HMDS spectrometer (Institute of Organic Chemistry PAS, Warsaw). Elemental analyses were performed in the Laboratory of the Polish Academy of Science (CBMiM) in Łódź.

Starting materials. All solvents and reagents are commercially available and were used as received. Thioketones $(\mathbf{2} \mathbf{a}-\mathbf{2 i})$ were obtained in a typical manner from the corresponding ketones and Lawesson's reagent in boiling toluene or benzene. ${ }^{13,22}$ Diphenylketene (1) was obtained from diphenylacetyl chloride via reaction with triethylamine at $0{ }^{\circ} \mathrm{C}$ according to literature procedures. ${ }^{23}$

Reaction of thioketones (2) with diphenylketene (1). - General procedure. To a mixture of 1 mmol of the corresponding thioketone (2) and a crystal of hydroquinone to inhibit polymerization, $1.1 \mathrm{mmol}$ of the yellow oil of freshly prepared diphenylketene (1) were added dropwise at room temperature under an argon atmosphere. The resulting mixtures were kept at room temperature until the color of $\mathbf{2}$ disappeared completely (ca. $48 \mathrm{~h}$ for $\mathbf{2 a}-\mathbf{2 d}$, ca. $24 \mathrm{~h}$ for $\mathbf{2 e}, \mathbf{2 f}$, and ca. $0.5 \mathrm{~h}$ for $\mathbf{2 g}-\mathbf{2 i}$ ). The crude mixtures were purified chromatographically on silica gel using a mixture of hexane and $\mathrm{CH}_{2} \mathrm{Cl}_{2}(3.5: 1.5)$ as eluent. In the reactions with less reactive thioketones $(\mathbf{2} \mathbf{a}-\mathbf{2 d})$, benzophenone was isolated as the more polar fraction in variable amounts depending on the type of thioketone 2 used (traces - 20\% yield). The obtained products were additionally purified by crystallization from hexane or petroleum ether with a small amount of $\mathrm{CH}_{2} \mathrm{Cl}_{2}$.

3,3,4,4-Tetraphenylthietan-2-one (3a). ${ }^{3 \mathrm{c}}$ Yield: $242 \mathrm{mg}(62 \%)$. Colorless crystals, $\mathrm{mp} 138{ }^{\circ} \mathrm{C}$ (dec.). IR (KBr): 3059m, 3027m, 1732vs (C=O), 1540m, 1489s, 1443m, 1048s, 824s, 748s, 720s. ${ }^{1} \mathrm{H}-\mathrm{NMR}$ : 7.06-7.12 (m, $\left.16 \mathrm{H}_{\text {arom}}\right)$; 7.13-7.16 (m, $\left.4 \mathrm{H}_{\text {arom }}\right) .{ }^{13} \mathrm{C}-\mathrm{NMR}: 63.5,93.2\left(2 \mathrm{C}_{\mathrm{q}}\right)$; 126.9, 127.2, 127.3, 127.8, 129.2, $130.8\left(20 \mathrm{CH}_{\text {arom}}\right) ; 138.4,141.8$ (4 $\left.\mathrm{C}_{\text {arom }}\right)$; $194.6(\mathrm{C}=\mathrm{O})$. HR-ESI-MS $\left(\mathrm{MeOH} / \mathrm{CHCl}_{3}+\mathrm{NaOH}\right)$ : 415.11271 (calcd. 415.11297 for $\mathrm{C}_{27} \mathrm{H}_{20} \mathrm{NaOS}[M+\mathrm{Na}]^{+}$).

3',3'-Diphenylspiro[fluorene-9,4'-thietane]-2'-one (3b). Yield: $268 \mathrm{mg}$ (69\%). Colorless crystals, mp $168{ }^{\circ} \mathrm{C}$ (dec.). IR (KBr): 3060m, 3036m, $1753 v s(\mathrm{C}=\mathrm{O}), 1636 \mathrm{~s}, 1490 \mathrm{~m}, 1447 \mathrm{~m}, 1338 \mathrm{~m}, 1091 \mathrm{~m}, 1054 \mathrm{~s}$, $809 m, 739 \mathrm{~s}, 703 m .{ }^{1} \mathrm{H}-\mathrm{NMR}: 6.75\left(d, J_{\mathrm{H}, \mathrm{H}}=7.6 \mathrm{~Hz}, 2 \mathrm{H}_{\text {arom }}\right) ; 6.96\left(d t, J_{\mathrm{H}, \mathrm{H}}=7.6,0.7 \mathrm{~Hz}, 2 \mathrm{H}_{\text {arom }}\right)$; 7.09-7.13 ( $\left.m, 10 \mathrm{H}_{\text {arom }}\right) ; 7.31\left(d t, J_{\mathrm{H}, \mathrm{H}}=7.5,0.5 \mathrm{~Hz}, 2 \mathrm{H}_{\text {arom }}\right) ; 7.71\left(d, J_{\mathrm{H}, \mathrm{H}}=7.6 \mathrm{~Hz}, 2 \mathrm{H}_{\text {arom }}\right) .{ }^{13} \mathrm{C}-\mathrm{NMR}$ : 59.0, $90.5\left(2 \mathrm{C}_{\mathrm{q}}\right)$; 119.8, 127.0, 127.1, 127.5, 127.9, $128.8\left(18 \mathrm{CH}_{\text {arom }}\right) ; 140.3,140.4$, $145.2\left(6 \mathrm{C}_{\text {arom }}\right)$; $194.7(\mathrm{C}=\mathrm{O})$. HR-ESI-MS (MeOH/CHCl$\left.{ }_{3}+\mathrm{NaOH}\right)$ : 413.09706 (calcd. 413.09706 for $\mathrm{C}_{27} \mathrm{H}_{18} \mathrm{NaOS}$ $\left.[M+\mathrm{Na}]^{+}\right)$. 
3',3'-Diphenylspiro[5H-dibenzo[a,d]cyclohepten-5,4'-thietane]-2-one (3c). Yield: $298 \mathrm{mg}(72 \%)$. Colorless crystals, mp $167{ }^{\circ} \mathrm{C}$ (dec.). IR (KBr): 3022m, 2956m, 1748vs (C=O), 1705m, 1596m, 1492m, 1478m, 1436m, 1327m, 1186m, 1049m, 831s, 765m, 727s, 697s, 645m. ${ }^{1} \mathrm{H}-\mathrm{NMR}: 6.54(s, 2 \mathrm{CH}=)$; $6.99(t$, $\left.J_{\mathrm{H}, \mathrm{H}}=7.4 \mathrm{~Hz}, 4 \mathrm{H}_{\text {arom }}\right) ; 7.03-7.10\left(m, 8 \mathrm{H}_{\text {arom }}\right) ; 7.21\left(t, J_{\mathrm{H}, \mathrm{H}}=7.4 \mathrm{~Hz}, 2 \mathrm{H}_{\text {arom }}\right) ; 7.41\left(d t, J_{\mathrm{H}, \mathrm{H}}=7.6,1.1 \mathrm{~Hz}\right.$, $\left.2 \mathrm{H}_{\text {arom }}\right) ; 8.02\left(d, J_{\mathrm{H}, \mathrm{H}}=8.0 \mathrm{~Hz}, 2 \mathrm{H}_{\text {arom }}\right) .{ }^{13} \mathrm{C}-\mathrm{NMR}: 69.9,93.3\left(2 \mathrm{C}_{\mathrm{q}}\right) ; 126.8,126.9,127.3,128.3,128.4$, 128.8, 130.8, $132.9\left(18 \mathrm{CH}_{\text {arom }} 2 \mathrm{CH}=\right) ; 135.1,136.4,137.3\left(4 \mathrm{C}_{\mathrm{arom}}\right) ; 193.9(\mathrm{C}=\mathrm{O})$. Anal. Calcd for $\mathrm{C}_{29} \mathrm{H}_{20} \mathrm{OS}$ (416.54): C 83.62; H 4.84; S 7.70. Found: C 83.75; H 4.91 S 7.82.

3',3'-Diphenylspiro[10,11-dihydro-5H-dibenzo[a,d]cyclohepten-5,4'-thietane]-2-one (3d). Yield: 279 mg (67\%). Colorless crystals, mp $149^{\circ} \mathrm{C}$ (dec.). IR (KBr): 3024m, 2981m, 1743vs (C=O), $1701 \mathrm{~m}, 1597 \mathrm{~m}$, $1491 m, 1478 m, 1339 m, 1162 m, 1054 m, 834 s, 778 m, 726 s, 699 s, 626 m .{ }^{1} \mathrm{H}-\mathrm{NMR}: 2.59-2.64$ ( $m, 2 \mathrm{H}$, $\left.\mathrm{CH}_{2}\right)$; 3.18-3.22 (m, $\left.2 \mathrm{H}, \mathrm{CH}_{2}\right)$; 6.87-6.89 (m, $\left.2 \mathrm{H}_{\text {arom}}\right)$; 7.04-7.15 ( $\left.m, 14 \mathrm{H}_{\text {arom}}\right)$; 7.98-8.00 (m, $\left.2 \mathrm{H}_{\text {arom }}\right)$. ${ }^{13} \mathrm{C}-\mathrm{NMR}: 32.9\left(2 \mathrm{CH}_{2}\right)$; 71.5, $94.2\left(2 \mathrm{C}_{\mathrm{q}}\right)$; 126.1, 127.4, 127.6, 128.2, 129.9, 130.3, $130.4\left(18 \mathrm{CH}_{\text {arom }}\right)$; 136.3, 139.0, 139.5 (6 $\left.\mathrm{C}_{\text {arom }}\right)$; $194.6(\mathrm{C}=\mathrm{O})$. Anal. Calcd for $\mathrm{C}_{29} \mathrm{H}_{22} \mathrm{OS}$ (418.65): C 83.22; H 5.30; $\mathrm{S}$ 7.66. Found: C 83.35; H 5.27; S 7.71.

3,3,4-Triphenyl-4-(2-thienyl)thietan-2-one (3e). Yield: $270 \mathrm{mg}(68 \%)$. Pale yellow crystals, $\mathrm{mp} 146{ }^{\circ} \mathrm{C}$ (dec.). IR (KBr): 3059m, 3031m, 1735vs (C=O), 1598m, 1444s, 1236m, 1049m, 1000m, 827s, 753s, 699s. ${ }^{1} \mathrm{H}-\mathrm{NMR}: 6.59\left(d d, J_{\mathrm{H}, \mathrm{H}}=3.8,1.2 \mathrm{~Hz}, 1 \mathrm{H}_{\mathrm{arom}}\right) ; 6.67\left(d d, J_{\mathrm{H}, \mathrm{H}}=5.0,3.8 \mathrm{~Hz}, 1 \mathrm{H}_{\text {arom }}\right) ; 7.04-7.10(m, 6$ $\mathrm{H}_{\text {arom }}$ ); 7.21-7.28 (m, $\left.8 \mathrm{H}_{\text {arom }}\right)$; 7.43-7.46 (m, $2 \mathrm{H}_{\text {arom }) .}{ }^{13} \mathrm{C}-\mathrm{NMR}: 62.4,94.2\left(2 \mathrm{C}_{\mathrm{q}}\right) ; 126.3,126.9,127.2$, 127.6, 127.7, 127.9, 128.6, 129.2, 130.0, $130.2\left(18 \mathrm{CH}_{\text {arom }}\right) ; 137.2,138.5,140.1,150.8\left(4 \mathrm{C}_{\text {arom }}\right) ; 193.5$ $(\mathrm{C}=\mathrm{O})$. HR-ESI-MS (MeOH/CHCl$\left.{ }_{3}+\mathrm{NaOH}\right)$ : 421.06913 (calcd. 421.06902 for $\mathrm{C}_{25} \mathrm{H}_{18} \mathrm{NaOS}_{2}[M+\mathrm{Na}]^{+}$).

3,3,4-Triphenyl-(4-selenophen-2-yl)thietan-2-one (3f). Yield: $290 \mathrm{mg}$ (65\%). Pale brown crystals, mp $163{ }^{\circ} \mathrm{C}$ (dec.). IR (KBr): 3059m, 3029m, 1733vs (C=O), 1596m, 1489s, 1334m, 1282m, 1158m, 1118m, $1088 m, 1048 m, 1000 m, 827 s, 719 s, 647 m .{ }^{1} \mathrm{H}-\mathrm{NMR}: 6.75\left(d, J_{\mathrm{H}, \mathrm{H}}=3.7 \mathrm{~Hz}, 1 \mathrm{H}_{\mathrm{arom}}\right) ; 6.91\left(d d, J_{\mathrm{H}, \mathrm{H}}=5.6\right.$, $\left.4.0 \mathrm{~Hz}, 1 \mathrm{H}_{\text {arom }}\right) ; 7.03-7.11\left(m, 5 \mathrm{H}_{\text {arom }}\right) ; 7.21-7.29\left(m, 8 \mathrm{H}_{\text {arom }}\right) ; 7.49-7.50\left(m, 2 \mathrm{H}_{\text {arom }}\right) ; 7.79\left(d, J_{\mathrm{H}, \mathrm{H}}=\right.$ $\left.5.6 \mathrm{~Hz}, 1 \mathrm{H}_{\text {arom }}\right){ }^{13} \mathrm{C}-\mathrm{NMR}:$ 64.3, $94.3\left(2 \mathrm{C}_{\mathrm{q}}\right)$; 127.2, 127.3, 127.6, 127.7, 127.8, 127.9, 128.9, 129.0, 129.2, 130.0, 132.0, 133.1 (18 $\left.\mathrm{CH}_{\text {arom }}\right)$; 137.2, 138.6, 140.7, $159.1\left(4 \mathrm{C}_{\text {arom }}\right)$; $193.6(\mathrm{C}=\mathrm{O})$. Anal. Calcd for $\mathrm{C}_{25} \mathrm{H}_{18} \mathrm{OSSe}$ (445.44): C 67.41; H 4.07; S 7.20. Found: C 67.60; H 4.11; S 7.31.

4-(2-Furyl)-3,3-diphenyl-4-(2-thienyl)thietan-2-one (3g). Yield: $270 \mathrm{mg}$ (70\%). Yellow crystals, mp $136{ }^{\circ} \mathrm{C}$ (dec.). IR (KBr): 3039m, 3028m, 1746vs (C=O), 1599m, 1491s, 1375m, 1228m, 1156m, 1090m, 1044m, 1017m, 827s, 753s, 699s. ${ }^{1} \mathrm{H}-\mathrm{NMR}: 6.17$ (dd, $\left.J_{\mathrm{H}, \mathrm{H}}=3.2,1.8 \mathrm{~Hz}, 1 \mathrm{H}_{\text {arom }}\right) ; 6.24\left(d d, J_{\mathrm{H}, \mathrm{H}}=3.2,0.5\right.$ $\left.\mathrm{Hz}, 1 \mathrm{H}_{\text {arom }}\right) ; 6.77\left(d d, J_{\mathrm{H}, \mathrm{H}}=5.0,3.7 \mathrm{~Hz}, 1 \mathrm{H}_{\text {arom }}\right) ; 6.88\left(d d, J_{\mathrm{H}, \mathrm{H}}=3.6,1.1 \mathrm{~Hz}, 1 \mathrm{H}_{\text {arom }}\right) ; 7.10-7.14(m, 4$ 
$\left.\mathrm{H}_{\text {arom }}\right)$; 7.17-7.18 ( $\left.m, 2 \mathrm{H}_{\text {arom }}\right)$; 7.27-7.28 ( $\left.m, 4 \mathrm{H}_{\text {arom }}\right)$; 7.33-7.36 ( $\left.m, 2 \mathrm{H}_{\text {arom }}\right) .{ }^{13} \mathrm{C}-\mathrm{NMR}: 53.8,93.5(2$ $\left.\mathrm{C}_{\mathrm{q}}\right) ; 110.4,112.1,126.4,126.8,127.2,127.4,127.5,127.7,127.8,128.6,129.5,143.0\left(16 \mathrm{CH}_{\text {arom }}\right)$; 137.7, 138.0, 144.3, 153.6 (4 C arom); $192.6(\mathrm{C}=\mathrm{O})$. HR-ESI-MS ( $\left.\mathrm{MeOH} / \mathrm{CHCl}_{3}+\mathrm{NaOH}\right): 411.04826$ (calcd. 411.04839 for $\left.\mathrm{C}_{23} \mathrm{H}_{16} \mathrm{NaO}_{2} \mathrm{~S}_{2}[M+\mathrm{Na}]^{+}\right)$.

3,3-Diphenyl-4,4-bis(2-thienyl)thietan-2-one (3h): Yield: $278 \mathrm{mg}$ (69\%). Pale brown crystals, mp $130{ }^{\circ} \mathrm{C}$ (dec.). IR (KBr): 3066m, 3026m, 1743vs (C=O), 1599m, 1449m, 1348m, 1076m, 1056m, 809m, 752m, 702s. ${ }^{1} \mathrm{H}-\mathrm{NMR}:$ 6.73-6.75 ( $\left.m, 2 \mathrm{H}_{\text {arom }}\right)$; 6.77-6.78 ( $\left.m, 2 \mathrm{H}_{\text {arom }}\right)$; 7.11-7.17 ( $\left.m, 8 \mathrm{H}_{\text {arom }}\right)$; 7.26-7.28 ( $m, 4$ $\mathrm{H}_{\text {arom }) .}{ }^{13} \mathrm{C}-\mathrm{NMR}: 58.2,95.0\left(2 \mathrm{C}_{\mathrm{q}}\right) ; 126.4,126.5,127.5,127.8,128.7,129.6\left(16 \mathrm{CH}_{\text {arom }}\right) ; 137.6,147.4(4$ $\mathrm{C}_{\text {arom}}$ ); $192.6(\mathrm{C}=\mathrm{O})$. TOF-MS-ES: 405.0438 (calcd. 405.0442 for $\left.\mathrm{C}_{23} \mathrm{H}_{17} \mathrm{OS}_{3}[M+1]^{+},(56)\right), 427.0258$ (calcd. 427.0261 for $\mathrm{C}_{23} \mathrm{H}_{16} \mathrm{ONaS}_{3}[M+\mathrm{Na}]^{+}$, (100)).

3,3-Diphenyl-4,4-di(selenophen-2-yl)thietan-2-one (3i). Yield: $310 \mathrm{mg}$ (62\%). Pale brown crystals, mp $134{ }^{\circ} \mathrm{C}$ (dec.). IR (KBr): 3025w, 3001w, 1742vs (C=O), 1599m, 1492m, 1443m, 1383m, 1345m, 1229m, 1108m, 1029m, 858m, 694s. ${ }^{1} \mathrm{H}-\mathrm{NMR}: 6.98-7.02\left(m, 4 \mathrm{H}_{\mathrm{arom}}\right) ; 7.17-7.22\left(m, 6 \mathrm{H}_{\mathrm{arom}}\right) ; 7.35\left(d d, J_{\mathrm{H}, \mathrm{H}}=7.6\right.$, $\left.1.4 \mathrm{~Hz}, 4 \mathrm{H}_{\mathrm{arom}}\right) ; 7.87\left(d d, J_{\mathrm{H}, \mathrm{H}}=5.6,1.1 \mathrm{~Hz}, 2 \mathrm{H}_{\text {arom }}\right) .{ }^{13} \mathrm{C}-\mathrm{NMR}: 61.9,95.0\left(2 \mathrm{C}_{\mathrm{q}}\right) ; 127.7,127.8,129.0$, 131.7, 132.8 (16 $\left.\mathrm{CH}_{\text {arom}}\right)$; 137.7, 155.5 (4 $\left.\mathrm{C}_{\text {arom}}\right)$; $192.7(\mathrm{C}=\mathrm{O})$. HR-ESI-MS (MeOH/CHCl$\left.{ }_{3}+\mathrm{NaOH}\right)$ : 522.91445 (calcd. 522.91441 for $\mathrm{C}_{23} \mathrm{H}_{16} \mathrm{NaOSSe}_{2}[M+\mathrm{Na}]^{+}$).

X-Ray Crystal-Structure Determination of 3c (Figure 1). ${ }^{24}$ All measurements were made on an Agilent Technologies SuperNova area-detector diffractometer ${ }^{25}$ using $\operatorname{Mo} K \alpha$ radiation $(\lambda=0.71073 \AA$ ) from a micro-focus X-ray source and an Oxford Instruments Cryojet XL cooler. Data reduction was performed with CrysAlisPro. ${ }^{25}$ The intensities were corrected for Lorentz and polarization effects, and an empirical absorption correction using spherical harmonics ${ }^{25}$ was applied. Equivalent reflections were merged. The data collection and refinement parameters are given below. A view of the molecule is shown in the Figure. The structure was solved by direct methods using SHELXS-2013, ${ }^{26}$ which revealed the positions of all non-H-atoms. The non-H-atoms were refined anisotropically. All of the H-atoms were placed in geometrically calculated positions and refined by using a riding model where each $\mathrm{H}$-atom was assigned a fixed isotropic displacement parameter with a value equal to $1.2 \mathrm{U}_{\mathrm{eq}}$ of its parent C-atom. The refinement of the structure was carried out on $F^{2}$ by using full-matrix least-squares procedures, which minimized the function $\Sigma w\left(F_{\mathrm{o}}{ }^{2}-F_{\mathrm{c}}{ }^{2}\right)^{2}$. A correction for secondary extinction was not applied. Neutral atom scattering factors for non-H-atoms were taken from ref. ${ }^{27}$, and the scattering factors for $\mathrm{H}$-atoms were taken from ref. ${ }^{28}$ Anomalous dispersion effects were included in $F_{\mathrm{c}} ;{ }^{29}$ the values for $f$ and $f$ ' were those of ref. ${ }^{30}$ The values of the mass attenuation coefficients are those of ref. ${ }^{31}$ All calculations were performed using the 
SHELXL-2013 program. $^{26}$

Crystal data for 3c: Crystallized from hexane $/ \mathrm{CH}_{2} \mathrm{Cl}_{2}, \mathrm{C}_{29} \mathrm{H}_{20} \mathrm{OS}, M=416.54$, colorless, prism, crystal dimensions $0.20 \times 0.22 \times 0.22 \mathrm{~mm}$, triclinic, space group $P \overline{1}, Z=2$, reflections for unit cell determination $14381,2 \theta$ range for cell determination $4-61^{\circ}, a=8.9451(2) \AA, b=10.4239(3) \AA, c=12.1195(3) \AA, \alpha=$ 93.516(2) ${ }^{\circ}, \beta=102.270(2)^{\circ}, \gamma=108.964(2)^{\circ}, V=1033.85(5) \AA^{3}, D_{X}=1.338 \mathrm{~g} \cdot \mathrm{cm}^{-3}, \mu\left(\operatorname{Mo} K_{c}\right)=0.176$ $\mathrm{mm}^{-1}, T=160(1) \mathrm{K}, \omega$ scans, $2 \theta_{\max }=61.0^{\circ}$, transmission factors (min; max) $0.935 ; 1.000$, total reflections measured 26089, symmetry independent reflections 5834, reflections with $I>2 \sigma(I) 5170$, reflections used in refinement 5834, parameters refined 280, final $R(F)(I>2 \sigma(I)$ reflections $)=0.0374, w R\left(F^{2}\right)$ (all data) $=$ $0.0978\left(w=\left[\sigma^{2}\left(F_{\mathrm{o}}^{2}\right)+(0.0446 P)^{2}+0.3801 P\right]^{-1}\right.$ where $P=\left(F_{\mathrm{o}}{ }^{2}+2 F_{\mathrm{c}}{ }^{2}\right) / 3$, goodness of fit 1.054 , final $\Delta_{\max } / \sigma=0.001, \Delta \rho(\max ; \min )=0.36 ;-0.24 \mathrm{e} \AA^{-3}$.

\section{ACKNOWLEDGEMENTS}

G. M., K.U., and H. H. acknowledge the National Science Center (PL-Cracow) for financial support (Grant Maestro-3; Dec-2012/06/A/ST5/00219). We thank the analytical services of our institute for NMR spectra and PD Dr. L. Bigler, University of Zurich, for HR-ESI-MS.

\section{REFERENCES AND NOTES}

1. Part of the Master Thesis of A.S., University of Łódź, 2014.

2. H. Ulrich, Cumulenes in Click Reactions, Wiley, New York, 2009.

3. a) S. Kobayashi, T. Semba, T. Takahashi, S. Yoshida, K. Dai, T. Otani, and T. Saito, Tetrahedron, 2009, 65, 920; b) M. Hans, J. Wouters, A. Demonceau, and L. Delaude, Chem. Eur. J., 2013, 19, 9668; c) T.-Y. Jian, L. He, C. Tang, and S. Ye, Angew. Chem. Int. Ed., 2011, 50, 9104; d) N. Duguet, A. Donaldson, S. M. Leckie, J. Douglas, P. Shapland, T. B. Brown, G. Churchill, A. M. Z. Slawin, and A. D. Smith, Tetrahedron Asymmetry, 2010, 21, 582; e) O. Sereda, A. Blanrue, and R. Wilhelm, Chem. Commun., 2009, 1040; f) J.-P. Pradere, J. C. Roze, H. Quiniou, R. Danion-Bougot, D. Danion, and L. Toupet, Can. J. Chem., 1986, 64, 597; g) M. Mondal, A. A. Ibrahim, K. A. Wheeler, and N. J. Kerrigan, Org. Lett., 2010, 12, 1664; h) L. He, H. Lv, Y.-R. Zhang, and S. Ye, J. Org. Chem., 2008, 73, 8101 .

4. a) C. M. Rasik and M. K. Brown, J. Am. Chem. Soc., 2013, 135, 1673; b) F. Effenberger, P. Fischer, G. Prossel, and G. Kiefer, Chem. Ber., 1971, 104, 1987; c) R. Huisgen and R. A. Feiler, Chem. Ber., 1969, 102, 3391.

5. a) H. Staudinger, Helv. Chim. Acta, 1920, 3, 862; b) P. Rioult and J. Vialle, Bull. Chem. Soc. Fr., 1967, 2883; c) H. Kohn, P. Charumilind, and Y. Gopichand, J. Org. Chem., 1978, 43, 4961. 
6. V. N. Drozd and O. A. Popowa, J. Org. Chem. USSR (Engl. Transl.), 1983, 19, 946.

7. J. D. Coyle, P. A. Rapley, J. Kamphuis, and H. J. T. Bos, J. Chem. Soc., Perkin Trans. 1, 1985, 1957.

8. T. Karakasa, H. Yamaguchi, and S. Motoki, J. Org. Chem., 1980, 45, 927.

9. R. Couturier, D. Paquer, and A. Vibet, Bull. Soc. Chim. Fr., 1975, 1670.

10. N. Drinnan and C. Wentrup, Aust. J. Chem., 2014, 67, 525.

11. E. Vedejs, D. A. Perry, and R. G. Wilde, J. Am. Chem. Soc., 1986, 108, 2985.

12. R. Huisgen, G. Mloston, K. Polborn, and R. Sustmann, Chem. Eur. J., 2003, 9, 2256.

13. G. Mloston, K. Urbaniak. K. Gebicky, P. Grzelak, and H. Heimgartner, Heteroatom Chem., 2014, in print. DOI 10.1002/hc.21191

14. C. K. Johnson, ORTEP II, Report ORNL-5138, Oak Ridge National Laboratory, Oak Ridge, Tennessee, 1976.

15. H. Petzold, S. Bräutigam, H. Görls, W. Weigand, U. Uhlmann, R. Gessner, W. Kiefer, J. Popp, A. Majchrzak, and G. Mloston, Inorg. Chim. Acta, 2004, 357, 1897.

16. P. Charumilind and H. Kohn, J. Org. Chem., 1980, 45, 4359.

17. To the best of our knowledge, reactions of thiocarbonyl S-oxides (sulfines) with diphenylketene (1) have not been reported yet. On the other hand, thiobenzophenone S-oxide is well kown as a versatile building block, applied in cycloadditions as a reactive dipolarophile ${ }^{18}$ as well as a 1,3-dipole. ${ }^{19}$

18. a) B. F. Bonini, G. Maccagnani, A. Wagenaar, L. Thijs, and B. Zwanenburg, J. Chem. Soc., Perkin Trans. 1, 1972, 2490; b) B. F. Bonini, G. Maccagnani, G. Mazzanti, L. Thijs, G. E. Veenstra, and B. Zwanenburg, J. Chem. Soc., Perkin Trans. 1, 1978, 1218; c) B. F. Bonini, G. Maccagnani, G. Mazzanti. P. Pedrini, and B. Zwanenburg, Gazz. Chim. Ital., 1977, 107, 289; d) G. Mloston, A. Linden, and H. Heimgartner, Helv. Chim. Acta, 1996, 79, 31.

19. R. Huisgen, G. Mloston, K. Polborn, and F. Palacios-Gambra, Liebigs Ann./Recueil, 1997, 187.

20. Oxidative formation of benzophenone as a side product in some reactions performed with diphenylketene (1) was reported, e.g., a) H. Staudinger, Justus Liebigs Ann. Chem., 1907, 356, 51; b) P. D. Bartlett and R. E. McCluney, J. Org. Chem., 1983, 48, 4165.

21. a) M. Sakamoto, T. Nakai, H. Yanagisawa, and T. Kawasaki, Heterocycles, 2009, 77, 409; b) T. Nakai, K. Fukutomi, H. Yanagisawa, T. Kawasaki, and M. Sakamoto, Heterocycles, 2009, 79, 627; c) H. Lv, L. You, and S. Ye, Adv. Synth. Catal., 2009, 351, 2822; d) A. D. Smith, J. Douglas, L. C. Morrill, and E. Richmond, [2+2] Cycloaddition, in 'Methods and Applications of Cycloaddition Reactions in Organic Syntheses', ed. by N. Nishiwaki, J. Wiley \& Sons, New Jersey, 2014, p. 89.

22. M. Jesberger, T. P. Davis, and L. Barner, Synthesis, 2003, 1929.

23. a) E. C. Taylor, A. McKillop, and G. H. Hawks, Org. Synth., 1988, 6; b) A. E. Taggi, A. M. Hafez, H. Wack, B. Young, D. Ferraris, and T. Lectka, J. Am. Chem. Soc., 2002, 124, 6626. 
24. CCDC-1007912 contains the supplementary crystallographic data for this paper. These data can be obtained free of charge from the Cambridge Crystallographic Data Centre via www.ccdc.cam.ac.uk/data_request/cif.

25. CrysAlisPro, Version 1.171.37.31d, Agilent Technologies, Yarnton, Oxfordshire, England, 2011.

26. G. M. Sheldrick, Acta Crystallogr., Sect. A, 2008, 64, 112.

27. E. N. Maslen, A. G. Fox, and M. A. O'Keefe, in 'International Tables for Crystallography', ed. by A. J. C. Wilson, Kluwer Academic Publishers, Dordrecht, 1992, Vol. C, Table 6.1.1.1, p. 477.

28. R. F. Stewart, E. R. Davidson, and W. T. Simpson, J. Chem. Phys., 1965, 42, 3175.

29. J. A. Ibers and W. C. Hamilton, Acta Crystallogr., 1964, 17, 781.

30. D. C. Creagh and W. J. McAuley, in 'International Tables for Crystallography', ed. by A. J. C. Wilson, Kluwer Academic Publishers, Dordrecht, 1992, Vol. C, Table 4.2.6.8, p. 219.

31. D. C. Creagh and J. H. Hubbell, in 'International Tables for Crystallography', ed. by A. J. C. Wilson, Kluwer Academic Publishers, Dordrecht, 1992, Vol. C, Table 4.2.4.3, p. 200. 